DOI: https://doi.org/10.31933/jimt.v2i6 Received: 14 Juni 2021, Revised: 25 Juni 2021, Publish: 24 Juli 2021

JIMT
JUINASTI
JERALAL ILMU MANAJEMEN
TERAPAN

\title{
PENGENALAN DAN DEFINISI HUKUM SECARA UMUM (LITERATURE REVIEW ETIKA)
}

\author{
Asifah Elsa Nurahma Lubis ${ }^{1}$, Farhan Dwi Fahmi² \\ 1) Fakultas Ekonomi \& Bisnis, Universitas Mercu Buana, asifahnurahma1372@gmail.com \\ 2) Fakultas Ekonomi \& Bisnis, Universitas Mercu Buana, farhandwifahmi69@gmail.com
}

\section{Corresponding Author: Farhan Dwi Fahmi}

\begin{abstract}
Abstrak: Hukum diciptakan untuk dilaksanakan. Hukum tidak bisa lagi disebut sebagai hukum, apabila tidak pernah dilaksanakan.Pelaksanaan hukum selalu melibatkan manusia dan tingkah lakunya. Lembaga kepolisian diberi tugas untuk menangani pelanggaran hukum, kejaksaan disusun dengan tujuan untuk mempersiapkan pemeriksaan perkara di depan sidang pengadilan. Di negara Indonesia masih banyak orang-orang yang melanggar hukum atau peraturan.Peraturan-peraturan yang sudah disepakati dan ditulis ternyata masih banyak yang dilanggar.Hal tersebut tidak hanya di kalangan pemerintah, masyarakat, tetapi juga menyebar ke instansi-instansi termasuk lembaga pendidikan atau diperkuliahan dan sekolah-sekolah. Indonesia adalah negara hukum.Dalam hidup di lingkungan masyarakat maupun sekolah tidak lepas dari aturan-aturan yang berlaku, baik aturan yang tertulis maupun aturan yang tidak tertulis.Aturan-aturan tersebut harus ditaati sepenuhnya.Adanya aturan tersebut adalah agar tercipta kemakmuran dan keadilan dalam lingkungan masyarakat. Apabila aturan-aturan tersebut dilanggar, akan mendapatkan sanksi yang tegas. Tujuan penelitian ini adalah untuk memberikan pengetahuan lebih kepada masyarakat tentang definisi hukum secara umum, tujuan dan karakteristik hukum, jenis-jenis hukum yang ada di Indonesia dan lain-ain yang terdapat dalam rumusan masalah artikel ini.Metode yang digunakan dalam penulisan yaitu dengan mengumpulkan data dan informasi berdasarkan dengan melakukan penelusuran pustaka, pencarian sumber-sumber yang relevan danpencarian data melalui internet. Data dan informasi yang digunakan yaitu data dari skripsi, media elektronik, dan beberapa pustaka yang relevan.
\end{abstract}

Kata kunci: Hukum, Peraturan, dan Lembaga.

\section{PENDAHULUAN}

\section{Latar Belakang Masalah}

Hukum merupakan keseluruhan aturan maupun kaidah yang berlaku dalam suatu kehidupan bersama yang mengatur mengenai tingkah laku dimana dalam pelaksanaannya dapat dipaksakan dengan hadirnya suatu sanksi. Hukum mengatur hubungan hukum yang terdiri dari ikatan-ikatan antara individu dan masyarakat dan antara individu itu sendiri yang 
mana tercermin dalam hak dan kewajiban. Dalam usahanya mengatur, hukum menyesuaikan kepentingan perorangan dengan kepentingan masyarakat dengan sebaik-baiknya. Mengingat bahwa masyarakat itu sendiri dari individu-individu yang menyebabkan terjadinya interaksi, maka akan selalu terjadi konflik atau ketegangan antara kepentingan perorangan dan kepentingan perorangan dengan kepentingan masyarakat. Hukum berusaha menampung ketegangan atau konflik itu sebaik-baiknya.

Kemajuan suatu bangsa dapat dilihat dari tingkat ketaatan hukum warganya. Semakin tinggi ketaatan hukum warga suatu negara, akan semakin tertib kehidupan bermasyarakatnya. Sebaliknya, jika ketaatan hukum warga suatu negara rendah, yang berlaku adalah hukum rimba. Pentingnya ketaatan hukum dalam suatu negara sangat diperlukan untuk dijadikan pedoman oleh masyarakat sebagai aturan yang harus ditaati. Karena itu Indonesia sebagai negara hukum, dalam kehidupan masyarakatnya tidak lepas dari aturan-aturan yang berlaku, baik aturan yang tertulis maupun aturan yang tidak tertulis. Aturan-Aturan tersebut harus ditaati sepenuhnya. Aturan tersebut diharapkan dapat menciptakan ketertiban dalam lingkungan masyarakat. Karena itu pemberian sanksi atau hukuman terhadap pelanggar aturan perlu diberikan.

Negara Indonesia merupakan negara hukum (Pasal 1 ayat 3 UUD 1945), namun banyak warga negara yang melanggar hukum atau peraturan tersebut. Peraturan yang sudah disepakati, diberlakukan serta diterapkan dalam masyarakat, masih banyak yang dilanggar. Oleh karenanya masih perlu ditingkatkan lagi pemahaman dan pengetahuan masyarakat Indonesia mengenai hukum-hukum yang ada di Indonesia.

\section{Rumusan Masalah}

Berdasarkan latar belakang diatas, dapat dirumuskan permasalahan yang akan dibahas sebagai berikut :

1. Apa definisi hukum secara umum?

2. Apa saja tujuan, elemen, dan karakteristik hukum?

3. Apa maksud dari orang sebagai subjek hukum dan hak serta terciptanya kewajiban hukum?

4. Apa itu hukum civil dan objek hukum?

5. Bagaimana sitematika pembagian hukum perdata?

6. Apa definisi dan jenis kontrak?

7. Apa itu hukum kontak dan perikatan? 
8. Bagaimana aspek dan konsekuensi hukum yang timbul dari sebuah kontrak?

9. Bagaimana hubungan antara kontrak dan kesepakatan?

\section{KAJIAN PUSTAKA \\ Kajian Teori}

Kajian teori dalam artikel ini bersumber dari sebuah buku yang berjudul "Ilmu Pengantar Hukum"yang merupakan karangan dari Muhammad Sadi Is. Di dalam buku tersebut dijelaskan secara terperinci mengenai pengertian dari hukum.

\section{A. Pengertian Hukum Secara Etimologi}

1. Hukum

Kata hukum berasal dari bahasa Arab dan merupakan bentuk tunggal, kata jamaknya adalah "Alkas" yang selanjutnya diambil alih dalam bahasa Indonesia menjadi "Hukum". Di dalam pengertian hukum terkandung pengertian bertalian erat dengan pengertian yang dapat melakukan paksaan.

2. Recht

Recht berasal dari "Rectum" (bahasa latin) yang mempunyai arti bimbingan atau tuntunan, atau pemerintahan. Bertalian dengan rectum dikena kata Rex, yaitu orang yang pekerjaannya memberikan bimbingan atau memerintah.Rexjuga dapat diartikan "Raja" yang mempunyai Regimen yang artinya kerajaan.

3. Ius

Kata Ius (Latin) berarti hukum.Berasal dari bahasa Latin lubere artinya mengatur atau memerintah.Perkataan mengatur dan memerintah itu mengandung dan berpangkal pokok pada kewibawaan.Selanjutnya istilah Ius bertalian erat dengan Ius titia atau keadilan.

B. Pengertian Hukum Menurut Para Ahli Hukum Indonesia

1. Satjipto Rahardjo

Hukum adalah karya manusia berupa norma-norma berisikan petunjuk-petunjuk tingkah laku.Hukum merupakan pencerminan dari kehendak manusia tentang bagaimana seharusnya masyarakat dibina dan ke mana harus diarahkan.

2. J.C.T Simorangkir dan Woerjono Sastropramto

Hukum adalah peraturan-peraturan bersifat memaksa yang dibuat oleh badanbadan resmi yang berwajib, yang menentukan tingkah laku manusia dalam 
lingkungan masyarakat, pelanggaran terhadap peraturan-peraturan tafi berakibat diambilnya tindakan hukuman.

3. Sudikno Mertokusumo

Hukum adalah ketentuan atau pedoman tentang apa yang seharusnya dilakukan. Pada hakikatnya kaidah hukum merupakan perumusan pendapat atau pandangan tentang bagaimana seharusnya seseorang bertingkah laku.Sebagai pedoman kaidah hukum bersifat umum dan pasif.

4. Soedjono Dirdjosisworo

Hukum adalah gejala social, ia harus berkembang di dalam kehidupan manusia bersama. Ia tampil dalam menyerasikan pertemuan antara kebutuhan dan kepentingan warga masyarakat, baik yang sesuai maupun yang saing bertentangan.

5. Soerjono Soekanto dan Purnadi Purbacaraka

Menjelaskan pengertian yang diberikan oleh masyarakat terhadap hukum. Hokum diartikan sebagai berikut :
a. Hukum sebagai ilmu pengetahuan
b. Hukum sebagai suatu disiplin
c. Hukum sebagai kaidah
d. Hukum sebagai tata hokum
e. Hukum sebagai petugas
f. Hukum sebagai keputusan penguasa
g. Hukum sebagai proses pemerintahan
h. Hukum sebagai sikap tindak ajek atau peri kelakuan

Pada prinsipnya hukum merupakan persyaratan yang beraneka ragam menjamin adanya penyesuaian kebebasan dan kehendak seseorang dengan orang lain. Berdasarkan asumsi ini pada dasarnya hukum mengatur hubungan antara manusia di dalam masyarakat berdasarkan prinsip-prinsip yang beraneka ragam pula.Oleh sebab itu, setiap orang di dalam masyarakat wajib taat. 


\section{Kajian Artikel yang Relevan}

Beberapa penelitian yang relevan dalam penelitian ini antara lain:

a. Penelitian yang ditulis oleh Soerjono Soekanto yang berjudul "Kesadaran Hukum dan Kepatuhan Hukum”. Didalam penelitian tersebut, masalah tersebut dikaitkan dengan kebutuhan hukum terutama mengenai peraturan lalu lintas dan angkutan jalan raya. Contoh tersebut dipilih oleh karena peraturan lalu lintas dan angkutan jaan raya merupakan salah satu sub-sistem tata hukum yang mengatur masalah-masaah nonspiritual. Lagi pula masalah lalu lintas semakin luas daya cukupnya dalam kehidupan sehari-hari terutama di kota besar seperti Jakarta, antara lain karena semakin meningkatnya peranan komunikasi yang secara relatif akan dapat menetralisir masalah-masalah yang disebabkan karena seorang warga masyarakat secara sukaarea maupun secara terpaksa senantiasa menghadapi persoalan lalu lintas yang semakin lama semakin intensif.

Dalam penelitian tersebut didasarkan pada data kuantitatif dan data kualitatif yang diperoleh dari kalangan yang secara langsung berhubungan dengan lalu lintas dan angkutan jalan raya serta pengusaha taksi.Kalangan tersebut menyatakan adanya kecenderungan umum, bahwa kesadaran hukum para pengemudi kendaraan bermotor umum tidak menurun, oleh karena mereka telah dididik dan dibina secara intensif dan ekstensif.Sebab-sebab terjadinya kepatuhan hukum yang relatif rendah di kalangan pengemudi kendaraan bermotor umum adalah terlalu kakunya kewajiban-kewajiban ekonomis-materiil yang dibebankan kepada para pengemudi, dengan adanya kebutuhan mengenai setoran minimal yang hanya didasakan pada prinsip ekonomis belaka.

b. Penelitian yang dituis oleh Atang Hemawan Usman yang berjudul "Kesadaran Hukum Masyarakat dan Pemerintahan Sebagai Faktor Tegaknya Negara Hukum di Indonesia”. Masalah kepatuhan hukum atau ketaatan terhadap hukum merupakan suatu unsur saja dari persoalan yang lebih luas, yaitu kesadaran hukum. Dari berbagai arti hukum, salah satu diantaranya, hukum diartikan sehagai jaringan nilai-nilai yang merupakan refleksi dari suatu masyarakat. Masalah nilai-nilai dalam hukum erat kaitannya dengan kesadaran hukum. Hal itu dikarenakan kesadaran hukum merupakan suatu penilaian terhadap hukum yang ada serta hukum yangdikehendaki atau yang seharusnya ada. Kesadaran hukum dalam penelitian ini diartikan sebagai persepsi 
hukum individu atau masyarakat terhadap hukum. Persepsi tersebut mungkin sama mungkin pula tidak dengan hukum yang herlaku. Hukum dalam arti di sini menunjuk pada hukum yang berlaku dan hukum yang dicita-citakan. Dengan demikian hukum di sini meliputi baik hukum yang tertulis maupun hukum yang tidak tertulis.

Peningkatan kesadaran seyogianya dilakukan melalui penerangan dan penyuluhan hukum yang teratur atas dasar perencanaan yang mantap. Penyuluhan hukum bertujuan agar warga masyarakat mengetahui dan memahami hukumhukum tertentu. Penerangan dan penyuluhan hukum harus disesuaikan dengan masalah-masalah hukum yang ada dalam masyarakat pada suatu waktu yang menjadi sasaran penyuluhan hukum. Disisi lain bahwa kondisi penegak hukum di Indonesia yang sangat lemah menjadi sumber utama konflik dan kekerasan di berbagai daerah Indonesia. Apa yang terjadi di Sampit, Maluku, dan Poso misalnya, merupakan refleksi dari miskinnya kreativitas sosial dalam menyelesaikan konflik di antara mereka. Sekalipun telah dikenal adanya kearifan tradisional untuk meneyelesaikan konflik, seperti prinsip sintuvu maroso padapenduduk yang mendiami Poso atau prinsip kita semua basaudara pada masyarakat Poso. Kesadaran perilaku sosial serta struktur sosial yang dikenalinya hanya menyediakan kekerasan sebagai cara yang

efektif untuk menyelesaikan konflik.

Beberapa penelitian diatas hanya sebagai perbandingan dalam artikel ilmiah ini.Sebagaimana yang telah diteliti oleh beberapa pengamat dapat disimpukan bahwa masyarakat Indonesia masih kurang menyadari sebagaimana pentingnya hukum bagi suatu Negara. Oleh karenanya yang akan dibahas dalam artikel ini hanya beberapa pengertian dari berbagai jenis hukum yang ada di Indonesia yang bertujuan untuk menambah pengetahuan bagi pembaca.

\section{METODE PENULISAN ARTIKEL}

Metode yang digunakan dalam penulisan yaitu dengan mengumpulkan data dan informasi berdasarkan dengan melakukan penelusuran pustaka, pencarian sumber-sumber yang relevan danpencarian data melalui internet. Data dan informasi yang digunakan yaitu data dari skripsi, media elektronik, dan beberapa pustaka yang relevan. Adapun teknik

pengumpulan data yang dilakukan yaitu: 
1. Sebelum analisis data dilaksanakan, terlebih dahulu dilakukan studi pustakayang menjadibahan pertimbangan dan tambahan wawasan untuk penulismengenai lingkup kegiatan dan konsep-konsep yang tercakup dalam penulisan.

2. Untuk melakukan pembahasan analisis dan sintesis data-data yang diperoleh,diperlukan data referensi yang digunakan sebagai acuan, dimana data tersebutdapat dikembangkan untuk dapat mencari kesatuan materi sehingga diperolehsuatu solusi dan kesimpulan.

\section{PEMBAHASAN}

\section{Definisi Hukum Secara Umum}

Utrecht, hukum adalah himpunan peraturan (perintah dan larangan) yang mengurus tata tertib suatu masyarakat dan karena itu, harus ditaati oleh masyarakat itu.

EM Meyers, Hukum semua aturan yang mengandung pertimbangan kesusilaan, ditujukan kepada tingkah laku manusia dalam masy, dan yg menjadi pedoman bagi penguasa-penguasa negara dalam menjalankan tugasnya.

Hukum adalah ketentuan-ketentuan yang menjadi peraturan hidup suatu masyarakat yang bersifat kendalikan, mencegah, mengikat, memaksa. Dinyatakan atau dianggap sebagai peraturan yang mengikat bagi sebagian atau seluruh anggota masyarakat tertentu, dengan tujuan untuk mengadakan suatu tata yang dikehendaki oleh penguasa tersebut.

Hukum merupakan serangkaian aturan yang berisi perintah ataupun larangan yang sifatnya memaksa demi terciptanya suatu kondisi yang aman, tertib, damai dan tentram, serta terdapat sanksi bagi siapapun yang melanggarnya.

\section{Tujuan, Elemen, dan Karakteristik Hukum}

A. Tujuan Hukum

Dasar yang terdapat pada tujuan hukum adalah mewujudkan kedamaian, ketertiban, kesejahteraan, serta ketentraman dalam kehidupan masyarakat dengan sifatnya yang universal.Melalui ketentuan hukum, segala bentuk perkara akan dapat diselesaikan dengan proses peradilan yang sesuai dengan ketentuan hukum tersebut.

Adapun tujuan hukum secara umum terdiri dari sebagai berikut ini.

a) Interaksi manusia yang terjadi dalam masyarakat dapat diatur dengan adanya hukum.

b) Mampu menjamin keamanan, kebahagiaan, serta kenyamanan bagi setiap individu di dalam masyarakat. 
c) Mampu memberikan upaya dalam memakmurkan seluruh anggota masyarakatnya.

d) Keadilan sosial seluruh masyarakat dapat terlaksana dan terwujudkan.

e) Mampu menjadi suatu petunjuk dalam melakukan pergaulan bagi setiap individu di dalam masyarakat.

f) Hukum bertujuan sebagai sarana penegak bagi proses pembangunan.

Tujuan Hukum Menurut Para Ahli :

a) Mochtar Kusumaatmadja

Tujuan hukum menurut Mochtar Kusumaatmadja adalah menciptakan sebuah ketertiban sehingga menjadi pokok terciptanya sebuah struktur sosial yang teratur. Selain itu, hukum memiliki tujuan lain yakni membuat keadilan yang sesuai dengan masyarakat dan zaman dapat tewujud.

b) Jeremy Bentham (1990)

Menurut ahli bernama Jeremy Bentham (1990), tujuan hukum ialah guna mencapai kemanfaatan. Artinya hukum akan dan dapat menjamin kebahagiaan orang banyak, teori tersebut juga dikenal dengan teori utilities.

c) Aristoteles

Sebagai seorang ahli, aristoteles mengungkapkan tujuan hukum adalah guna mencapai sebuah keadilan, artinya memberikan kepada setiap orang atas apa yang sudah menjadi haknya. Teori itu kini dikenal sebagai teori etis.

d) Geny

Sedangkan menurut Geni (1994) tujuan hukum merupakan untuk mencapai adanya keadilan dan juga sebagai unsur keadilan. Unsur keadilan yaitu kepentingan dayaguna serta kemanfaatan.

e) Immanuel Kant

Tujuan hukum selanjutnya menurut Immanuel Kant adalah keseleruhan syarat yang dengan kehendak bebas dari orang yang satu dapat menyesuaikan diri dengan lainnya untuk menuruti peraturan hukum soal kemerdekaan.

B. Elemen Hukum

Menurut Lawrence Milton Friedman, bahwa dalam sistem hukum harusmeliputi substansi, struktur, dan budaya hukum. Ketiga elemen ini menggambarkan bagaimana sistem hukum ditata secara substantif, apa yang dijalankan oleh sistem hukum itu, 
bagaimana sistem hukum itumenjalankannya, dan pada gilirannya akan melihat tingkat kesadaran terhadap hukum.

Ketiga komponen dalam sistem hukum menurut Lawrence Milton Friedman itudijabarkan lebih lanjut oleh Achmad Ali, yaitu :

a) Struktur hukum, yaitu keseluruhan institusi-institusi hukum yang ada besertaaparatnya, mencakup antara lain Kepolisian dengan para Polisinya, Kejaksaan denganpara Jaksanya, Pengadilan dengan para Hakimnya, dan lain-lain.

b) Substansi hukum, yaitu keseluruhan aturan hukum, norma hukum, dan asas hukum,baik yang tertulis maupun yang tidak tertulis, termasuk putusan pengadilan.

c) Kultur hukum yaitu : opini-opini, kepercayaan-kepercayaan (keyakinankeyakinan,kebiasaan-kebiasaan, cara berfikir, dan cara bertindak, baik dari para penegak hukummaupun dari warga masyarakat, tentang hukum dan berbagai fenomena yangberkaitan dengan hukum.

Unsur struktur hukum (legal structur) merupakan institusionalisasi ke dalam entitasentitas hukum seperti struktur pengadilan tingkat pertama, banding, dan kasasi, jumlah hakim serta integrated justice system. Substansi hukum menyangkut keseluruhan substansi aturanhukum yang mengandung norma-norma, asas-asas, prinsip-prinsip, dan kaidah-kaidah, baikyang tertulis maupun yang tidak tertulis, termasuk putusan pengadilan. Budaya hukummenyangkut sikap-sikap, tingkah laku, dan nilai-nilai yang berhubungan dengan hukum.

Struktur hukum, substansi hukum, dan budaya hukum merupakan elemenelemenpenting dalam penegakan hukum, jika salah satu elemen dari tiga kompenen ini tidak bekerja atau tidak berfungsi dengan baik, dapat mengganggu sistem hukum, sehingga munculahpersoalan (problem) hukum.

C. Karakteristik Hukum

Sebagai suatu hal yang menjadi ilmu khusus, hukum dapat dikenal melalui beberapa karakteristik yang dimilikinya. Beberapa karakteristik dari hukum tersebut terdiri dari sebagai berikut ini.

a. Adanya Perintah atau Larangan

Maksud dari karakteristik ini adalah hukum merupakan suatu hal yang boleh dan tidak boleh dilakukan oleh setiap individu di dalam masyarakat.

b. Bersifat Memaksa 
Dalam karakteristik ini, setiap individu memiliki kewajiban untuk mematuhi hukum yang telah ditetapkan ditetapkan tanpa adanya pengecualian.

c. Terdapat Sanksi

Karakteristik ini menunjukkan bahwa didalam hukum terdapat hukuman untuk pelanggar hukum berdasarkan ketentuan yang telah berlaku.

\section{Orang Sebagai Subyek Hukum dan Hak Serta Terciptanya Kewajiban Subjek Hukum}

Ketika berbicara hukum, yang paling awal ditanyakan adalah untuk apa hukum dibentukdan siapa yang menerima atau memeberlakukan hukum tersebut, tidak lain ia adalah subjek hukum. Subjek hukum ialah segala sesuatu yang dapat menjadi pendukung hak dan kewajiban. Dengan adanya hukum maka hak dan kewajiban subjek hukum dapat dikontrol yang bertujuan untuk mengatur dan melindungi atas semua perbuatan yang ia lakukan. Jenis subjek hukum dapat dibedakan menjadi dua yaitu subjek hukum manusia dan subjek hukum badan hukum.

Manusia sebagai subjek hukum, sejak saat dia dilahirkan dan berakhir pada saat dia meninggal dunia, bahkan seorang yang masih dalam kandungan ibunya sudah bisa dapat dianggap sebagai pembawa hak (dianggap telah lahir), apabila kepentingannyamemerlukannya (untuk menjadi ahli waris). Namun ada beberapa golongan yang oleh hukum dipandang sebagaisubjek hukum yang tidak cakap hukum. maka dalam melakukan perbuatan-perbuatan hukum mereka harus diwakili atau dibantu oleh orang lain.

Pengertian secara yuridis ada dua alasan yang menyebutkan mengapa manusia sebagai subjek hukum, manusia sebagai subjek hukum mempunyai hak-hak subjek dan kewenangan hukum artinya kecakapan untuk menjadi subjek hukum, yaitu sebagai pendukung hak dan kewajiban. Namun tidak semua manusia mempunyai kewenangan dan kecakapan untuk melakukan perbuatan hukum, orang yang dapat melakukan perbuatan hukum adalah orang yang sudah dewasa atau sudah kawin, sedangkan orang-orang yang tidak cakap melakukan perbuatan hukum adalah orang yang belum dewasa, orang ditaruh di bawah pengampuan, seorang wanita yang bersuami, dan orang yang tidak sehat rohani atau jiwanya.

Selain manusia sebagai pembawa hak dan kewajiban, badan hukum juga sebagai subjek hukum yaitu memiliki hak dan kewajiban dalam melakukan perbuatan-perbuatan 
hukum sepertilayaknya seorang manusia. Badan hukum itu mempunyai kekayaan sendiri, dan ikut serta dalamlalu lintas hukum dengan perantara pengurusnya. Ia dapat digugat dan dapat juga menggugat dimuka Pengadilan. Badan hukum juga dapat dikatakan sebagai rechtspersoon, yang berarti orangyang diciptakan oleh hukum.

Hak memiliki pengertian tentang sesuatu hal yang benar, memiliki, kepunyaan, kewenangan, kekuasaan untuk berbuat sesuatu (karena telah ditentukan olehUndangUndang, aturan, dan lain sebagainya), kekuasaan yang benar atas sesuatu atau untukmenuntut sesuatu, derajat atau martabat. Adapun kewajiban adalah sesuatu yang wajibdilaksanakan, keharusan (sesuatu hal yang harus dilaksanakan). Jenis-jenis hak atas subjek hukum tersebut meliputi :

a) Hak legal dan Hak Moral, hak legal adalah hak yang didasarkan atas hukum dalam salah satu bentuk. Hak legal ini lebih banyak berbicara tentang hukum atau sosial, dan hak moral adalahdidasarkan atas prinsip atau peraturan etis saja. hak moral lebih bersifat soliderisasi atau individu.

b) Hak Khusus dan Hak Umum, hak khusus timbul dalam suatu relasi khusus antara beberapa manusia karena fungsi khusus yang dimiliki orang satu terhadap orang lainnya, dan hakumum dimiliki manusia bukan karena hubungan atau fungsi tertentu, melainkan semata-matakarena ia manusia. Hak ini dimiliki oleh semua manusia tanpa terkecuali.

c) Hak Individual dan Hak Sosial, hak individual disini menyangkut pertama-tama adalah hak yang dimiliki individu-individu terhadap Negara. Negara tidak boleh menghindari ataumenggangu individu dalam mewujudkan hak-hak yang ia miliki, dan hak sosial disini bukanhanya hak kepentingan terhadap Negara saja, akan tetapi sebagai anggota masyarakatbersama dengan anggota-anggota lain. Inilah yang disebut dengan hak sosial.

Kewajiban sebagai subjek hukum bahwasanya ia harus patuh pada peraturan, norma, mengenai hal apa yang dapat dilakukan dan tidak dapat dilakukan, serta bertujuan untuk penertiban dan upaya agar terwujudnya cita-cita dari hukum itu sendiri, yang memberikan suatukepastian, keadilan, dan kemanfaatan di dalam kehidupan bermasyarakat. Disamping itu subjekhukum juga berkewajiban untuk menghormati dan menghargai setiap hak-hak subjek hukumlainnya yang ada di dalam masyarakat. Sehingga hak dan kewajiban merupakan sesuatu yangtidak dapat dipisahkan, akan tetapi terjadi pertentangan apabila hak dan kewajiban tidakseimbang. Setiap masyarakat memiliki hak dan kewajiban untuk 
mendapatkan penghidupan yang layak, tetapi pada kenyataannya banyak masyarakat yang belum merasakan kesejahteraan dalam menjalani kehidupan.

\section{Hukum Civil dan Objek Hukum}

A. Pengertian Hukum Civil Law

Hukum sipil (civil law) adalah sistem hukum yang berkembang di dataran Eropa. Titik tekan pada sistem hukum ini adalah, penggunaan aturan-aturan hukum yang sifatnya tertulis. Sistem hukum ini berkembang di daratan Eropa sehingga dikenal juga dengan sistem Eropa Kontinental. Kemudian disebarkan negara-negara Eropa Daratan kepada daerah-daerah jajahannya.

B. Karakteristik Sistem Civil Law

Karakteristik utama yang menjadi dasar sistem Hukum Civil Law adalah hukum memperoleh kekuatan mengikat, karena diwujudkan dalam peraturan-peraturan yang berbentuk undang-undang dan tersusun secara sistematik di dalam kodifikasi. Karakteristik dasar ini dianut mengingat bahwa nilai utama yang merupakan tujuan hukum adalah kepastian hukum. Hakim hanya berfungsi menetapkan dan menafsirkan peraturan-peraturan dalam batas-batas wewenangnya.

Karakteristik kedua pada sistem Civil Law tidak dapat dilepaskan dari ajaran pemisahan kekusaan yang mengilhami terjadinya Revolusi Perancis. Menurut Paul Scolten, bahwa maksud sesungguhnya pengorganisasian organ-organ negara Belanda adalah adanya pemisahan antara kekuasaan pembuatan undang-undang, kekuasaan peradilan, dan sistem kasasi adalah tidak dimungkinkannya kekuasaan yang satu mencampuri urusan kekuasaan lainnya. Penganut sistem Civil Law memberi keleluasaan yang besar bagi hakim untuk memutus perkara tanpa perlu meneladani putusan-putusan hakim terdahulu. Yang menjadi pegangan hakim adalah aturan yang dibuat oleh parlemen, yaitu undang-undang.

Karakteristik ketiga pada sistem hukum Civil Law adalah apa yang oleh Lawrence Friedman disebut sebagai digunakannya sistem Inkuisitorial dalam peradilan. Di dalam sistem itu, hakim mempunyai peranan yang besar dalam mengarahkan dan memutuskan perkara; hakim aktif dalam menemukan fakta dan cermat dalam menilai alat bukti. Menurut pengamatan Friedman, hakim di dalam sistem hukum Civil Law berusaha untuk mendapatkan gambaran lengkap dari peristiwa yang dihadapinya sejak awal. Sistem ini mengandalkan profesionalisme dan kejujuran hakim. 


\section{Sumber Hukum Civil Law}

Sumber-sumber yang menjadi rujukan pertama dalam tradisi sistem hukum Civil Law adalah peraturan perundang-undangan. Negara-negara penganut civil law menempatkan konstitusi pada urutan tertinggi dalam hirarki peraturan perundangundangan. Semua negara penganut civil law mempunyai konstitusi tertulis. Peraturan perundang-undangan mempunyai dua karakteristik, yaitu berlaku umum dan isinya mengikat keluar. Sifat yang berlaku umum itulah yang membedakan antara perundangundangan dan penetapan. Penetapan berlaku secara individual tetapi harus dihormati oleh orang lain.

Sumber hukum yang kedua yang dirujuk oleh para yuris di negara-negara penganut Civil Law dalam memecahkan masalah adalah kebiasaan-kebiasaan. Pada kenyataannya, undang-undang tidak pernah lengkap. Kehidupan masyarakat begitu kompleks sehingga undang-undang tidak mungkin dapat menjangkau semua aspek kehidupan tersebut. Sedangkan dilain pihak, dibutuhkan aturan-aturan yang dijadikan pedoman manusia dalam bertingkah laku untuk hidup bermasyarakat.

Sumber hukum yang ketiga yang dirujuk dalam sistem hukum Civil Law adalah yurisprudensi. Ketika mengemukakan bahwa suatu hukum kebiasaan berlaku bagi semua anggota masyarakat secara tidak langsung, melainkan melalui yurisprudensi, Spruit sebenarnya mengakui bahwa yurisprudensi merupakan sumber hukum dalam arti formal. Akan tetapi posisi yurisprudensi sebagai sumber hukum di dalam sistem hukum Civil Law belum lama diterima. Hal itu disebabkan oleh pandangan bahwa aturan-aturan tingkah laku, terutama aturan perundang-undangan, ditujuka untuk mengatur situasi yang ada dan menghindari konflik; dengan demikian, aturan-aturan itu dibuat untuk hal-hal setelah undang-undang itu diundangkan. Undang-undang dalam hal demikian merupakan suatu pedoman mengenai apa yang boleh dan yang tidak boleh dilakukan.

\section{Objek Hukum}

Objek hukum adalah segala sesuatu yang bermanfaat bagi subyek hukum dan dapat menjadi obyek dalam suatu hubungan hukum. Misalkan benda-benda ekonomi, yaitu benda-benda yang untuk dapat diperoleh manusia memerlukan "pengorbanan" dahulu sebelumnya. Hal pengorbanan dan prosedur perolehan benda-benda tersebut inilah yang menjadi sasaran pengaturan hukum dan merupakan perwujudan dari hak dan kewajiban 
subjek hukum yang bersangkutan sehingga benda-benda ekonomi tersebut menjadi objek hukum.

\section{Sistematika Pembagian Hukum Perdata}

Berdasarkan ilmu pengetahuan, hukum perdata dapat dibagi atas 4 bagian, yaitu :

a) Hukum tentang orang (Personenrecht) diatur dalam Bab I dan II buku II serta buku IV bab IV KUH Perdata yang memuat hal-hal tentang manusia sebagai subjek hukum, kecakapan untuk memiliki hak-hak,kecakapan untuk bertindak sendiri melaksanakan hak-haknya itu,serta hal lain yang mempengaruhi kecakapan, domisili, nama, pencatatan sipil (burgerlijk stand).

b) Hukum keluarga (Familierecht) diatur dalam Bab IV - XVIII buku I KUH Perdata yang memuat hal-hal yang berhubungan dengan hubungan hukum yang timbul dari hubungan kekeluargaan seperti perkawinan beserta hubungannya dalam harta kekayaan antara suami istri,hubungan antara orang tua dan anak, perwalian, pengampuan (curatele) serta perceraian.

c) Hukum kekayaan /hukum harta kekayaan/ hukum harta benda (Vermogensrecht) diatur dalam Bab I-IX dan XIX - XXI buku II serta Bab I - XVIII buku III KUH Perdata yang memuat hal-hal yang berhubungan tentang sesuatu yang dapat dinilai dengan uang, yang terdiri dari : pertama, Hukum kekayaan mutlak (absolut) yang meliputi hak-hak kebendaan material dan immaterial seperti, hak atas merek, hak cipta,dan hak oktroi, dan Kedua, Hukum harta kekayaan relative (nisbi) yaitu hak yang timbul dari suatu perikatan.

d) Hukum kewarisan (Erfrecht) diatur dalam Bab XII - XVIII buku II KUH Perdata yang memuat hal-hal yang berkaitan dengan pengalihan tentang benda atau kekayaan seorang jika telah meninggal dunia.

Sedangkan, apabila dilihat dari peraturan hukumnya yaitu KUHPerdata (BW), maka hukum dapat dibagi menjadi 4 (empat) bagian, yaitu :

a) Buku I : Tentang orang (Ven Person) dan hukum keluarga (Van Familie);

b) Buku II : Tentang Benda (Van Zaken), yang didalamnya termasuk hukum waris (Erf Recht);

c) Buku II: Tentang Perikatan (Verbintenissen Recht) atau hukum perjanjian (Verbintenissen); 
d) Buku IV : Tentang Pembuktian (Van Bewijk) dan Kedaluwarsa (Verjaring).

\section{Definisi dan Jenis Kontrak}

Hukum kontrak adalah norma/ kaidah/ aturan hukum yang mengatur hubungan antara belah pihak berdasarkan kata sepakat untuk menimbulkan akibat hukum dalam melaksanakan objek perjanjian atau prestasi. Perjanjin dan kontrak bersifat bebas, selama tidak melanggar ketertiban umum, kesusilaan dan lingkungan. Dalam pasal 1233 KUHPerdt disebutkan bahwa tiap perikatan dilahirkan oleh perjanjian dan UndangUndang.

Sedangkan pengertian hukum kontrak menurut para ahli :

a) Menurut Michael D Bayles, Pengertian Hukum Kontrak adalah aturan hukum yang berkaitan dengan pelaksanaan perjanjian atau persetujuan. Definisi hukum kontrak menurut bayles ini mengkaji hukum kontrak dari dimensi pelaksanaan perjanjian yang dibuat oleh para pihak, namun beliau tidak melihat pada tahap pra kontraktual dan kontraktual. Tahap tersebut merupakan tahap-tahap yang menentukan dalam penyusunan sebuah kontrak. Kontrak yang telah disusun oleh para pihak akan dilaksanakan mereka sendiri.

b) Menurut Lawrence M. Friedman, Pengertian Hukum Kontrak adalah perangkat hukum yang hanya mengatur aspek tertentu dari pasar dan mengatur jenis perjanjian tertentu. Apabila kita mengkaji aspek pasar, tentunya kita akan mengkaji dari berbagai aktivitas bisnis yang hidup dan berkembang dalam suatu market. Dalam berbagai market tersebut, terdapat berbagai macam kontrak yang dilakukan oleh para pelaku usaha yang mengadakan perjanjian jual beli, beli sewa, sewa-menyewa, leasing dan lain-lain.

c) Menurut Charles L. Knap dan Nathan M. Crystal, Hukum Kontrak ialah hukum yang melindungi harapan-harapan yang timbul dalam pembuatan persetujuan demi perubahan masa datang yang bervariasi kinerja, seperti pengangkutan kekayaan (yang nyata maupun yang tidak nyata), kinerja pelayanan dan pembayaran tersebut dengan uang.

Adapun jenis-jenis dari Hukum Kontrak, yaitu :

a. Kontrak Menurut Sumber Hukumnya.

Kontrak menurut sumber hukumnya merupakan penggolongan kontrak yang didasarkan pada tempat kontrak itu ditemukan. 
b. Kontrak Menurut Namanya.

Didalam Pasal 1319 KUHPerdata dan Artikel 1355 NBW hanya disebutkan dua macam kontrak menurut namanya, yaitu:

1) Kontrak Nominaat (Bernama).

Kontrak Nominat adalah kontrak yang dikenal dalam KUHPerdata. Yang termasuk dalam kontrak nominat adalah jual beli, tukar-menukar, pinjammeminjam, pemberian kuasa, sewa-menyewa, dll.

2) Kontrak Innominaat (Tidak Bernama).

Kontrak Innominaat ialah Kontrak yang timbul, tumbuh, dan berkembang dalam masyarakat. Yang termasuk dalam kontrak innominaat adalah Leasing, beli sewa, franchise, kontrak rahim, joint venture, kontrak karya, keagenan, production sharing, dll.

c. Kontrak Menurut Bentuknya.

Didalam KUHPerdata, tidak disebut secara sistematis tentang bentuk kontrak. Namun apabila kita menelaah berbagai ketentuan yang tercantum dalam KUHPerdata maka kontrak menurut bentuknya dapat dibagi menjadi dua macam, yaitu:

1) Kontrak Lisan.

Kontrak Lisan adalah kontrak atau perjanjian yang dibuat oleh para pihak cukup dengan lisan atau kesepakatan para pihak (Pasal 1320 KUHPerdata).

2) Kontrak Tertulis.

Kontrak tertulis merupakan kontrak yang dibuat oleh para pihak dalam bentuk lisan. Hal ini dapat kita lihat pada perjanjian hibah yang harus dilakukan dengan akta notaris (Pasal 1682 KUHPerdata).

Kontrak ini dibagi menjadi dua macam:

a) Akta dibawah tangan adalah akta yang cukup dibuat dan ditandatangani oleh para pihak.

b) Akta yang dibuat oleh notaris, merupakan akta pejabat. Contohnya, baerita acara Rapat Umum Pemegang Saham ( RUPS) dalam suatu PT.

d. Kontrak Timbal Balik.

Kontrak Timbal Balik merupakan perjanjian yang dilakukan para pihak yang menimbulkan hak dan kewajiban-kewajiban pokok seperti pada jual beli, dan sewa menyewa. 
e. Perajanjian cuma-cuma atau dengan Alas Hak yang membebani.

Penggolongan ini didasarkan pada keuntungan salah satu pihak dan adanya prestasi dari pihak lainnya. Perjanjian cuma-cuma merupakan perjanjian yang menurut hukum hanyalah menimbulkan keuntungan bagi salah satu pihak. Contohnya: hadiah dan pijam pakai.

Sedangkan perjanjian dengan alas hak yang membebani merupakan perjanjian disamping prestasi pihak yang satu senantiasa ada prestasi (Kontrak) dari pihak lain, yang menurut hukum saling berkaitan. Contonya: A menjanjikan kepada B suatu jumlah tertentu. Jika B menyerahkan sebuah benda tertentu pula kepada A.

f. Perjanjian Berdasarkan Sifatnya.

Penggolongan ini didasarkan pada hak kebendaan dan kewajiban yang ditimbulkan dari adanya prjanjian tersebut.

Perjanjian menurut sifatnya dibagi menjadi dua macam, yaitu:

1) Perjanjian Kebendaan (Zakelijke Overeenkomst)

Perjanjian Kebendaan adalah suatu perjanjian yang ditimbulkan hak kebendaan diubah atu dilenyapkan, hal demikian untuk memenuhi perikatan. Contoh : Perjanjian pembebanan jaminan dan penyerahan hak milik.

2) Perjanjian Obligatoir

Perjanjian yang merupakan perjanjian yang menimbulkan kewajiban dari para pihak.

g. Perjanjian Dari Aspek Larangannya.

Penggolongan perjanjian berdasarkan larangannya merupakan penggolongan perjanjian dari aspek tidak diperkenankannya para pihak untuk membuat perjanjian yang bertentangan dengan Undang-undang, kesusilaan, dan ketertiban umum.

\section{Hukum Kontrak dan Perikatan}

A. Hukum Kontrak

Charles L. Knap dan Nathan M. Crystal, Hukum Kontrak ialah hukum yang melindungi harapan-harapan yang timbul dalam pembuatan persetujuan demi perubahan masa datang yang bervariasi kinerja, seperti pengangkutan kekayaan (yang nyata maupun yang tidak nyata), kinerja pelayanan dan pembayaran tersebut dengan uang.

B. Syarat Hukum Kontrak 
Untuk dapat dianggap sah secara hukum, ada 4 syarat yang harus dipenuhi sebagaimana diatur dalam Pasal 1320 Kitab Undang-Undang Hukum Perdata Indonesia:

a. Kesepakatan para pihak

b. Kecakapan para pihak

c. Mengenai hal tertentu yang dapat ditentukan secara jelas

d. Sebab/causa yang diperbolehkan secara hukum.

C. Definisi Perikatan

Menurut Prof. Soediman Kartohadiprodjo, S.H. Hukum perikatan ialah kaidah hukum yang mengatur hak dan kewajiban seseorang yang bersumber pada tindakannya dalam lingungan hukum kekayaan.

D. Dasar Hukum Perikatan

Dasar hukum perikatan berdasarkan KUH Perdata terdapat tiga sumber adalah sebagai berikut:

a. Perikatan yang timbul dari persetujuan (perjanjian).

b. Perikatan yang timbul dari undang-undang.

c. Perikatan terjadi bukan perjanjian, tetapi terjadi karena perbuatan melanggar hukum dan perwakilan sukarela.

E. Sumber Perikatan Berdasarkan Undang-Undang

a. Perikatan (Pasal 1233 KUH Perdata): Perikatan, lahir karena suatu persetujuan atau karena undang-undang. Perikatan ditujukan untuk memberikan sesuatu, untuk berbuat sesuatu, atau untuk tidak berbuat sesuatu.

b. Persetujuan (Pasal 1313 KUH Perdata): Suatu persetujuan adalah suatu perbuatan dimana satu orang atau lebih mengikatkan diri terhadap satu orang lain atau lebih.

c. Undang-undang (Pasal 1352 KUH Perdata): Perikatan yang lahir karena undangundang timbul dari undang-undang atau dari undang-undang sebagai akibat perbuatan orang.

\section{Aspek dan Konsekuensi Hukum Yang Timbul dari Sebuah Kontrak}

\section{Konsekuensi Hukum Jika Perjanjian Tidak Mencantumkan Tanggal Pembayaran}

\section{Prinsip Dasar Perjanjian}

Dalam hal ini, dalam menghadapi perjanjian dengan sebuah perusahaan yang menginginkan pembayaran dilakukan 14 hari kerja setelah servis diberikan.Namun, 
perusahaan itu tidak mau tanggal pembayaran dicantumkan di dalam perjanjian.Kami asumsikan, perjanjian tersebut merupakan perjanjian jual beli jasa.

Pasal 1313 Kitab Undang-Undang Hukum Perdata ("KUH Perdata"), menyebutkan bahwa:

Suatu persetujuan adalah suatu perbuatan dimana satu orang atau lebih mengikatkan dirinya terhadap satu orang lain atau lebih.

Dengan dibuatnya sebuah perjanjian, maka secara otomatis sudah terikat secara perdata dengan perusahaan tersebut, begitupun sebaliknya.

Agar perjanjian sah secara hukum, maka harus memenuhi syarat-syarat sah perjanjian yang diatur dalam Pasal 1320 KUH Perdata, yaitu;

1) kesepakatan mereka yang mengikatkan dirinya;

2) kecakapan untuk membuat suatu perikatan;

3) suatu pokok persoalan tertentu;

4) suatu sebab yang tidak terlarang.

Lebih lanjut, ketentuan Pasal 1338 KUH Perdata menyebutkan:

Semua persetujuan yang dibuat sesuai dengan undang-undang berlaku sebagai undangundang bagi mereka yang membuatnya.Persetujuan itu tidak dapat ditarik kembali selain dengan kesepakatan kedua belah pihak, atau karena alasan-alasan yang ditentukan oleh undang-undang.Persetujuan harus dilaksanakan dengan itikad baik.

\section{Langkah yang Dapat Ditempuh}

Apabila tanggal pembayaran tidak dicantumkan di dalam perjanjian tersebut, maka perjanjian ini dapat menimbulkan ketidakpastian hukum.Akan timbul perbedaan pendapat tentang kapan waktu pembayaran dilakukan, sehingga berpotensi menimbulkan sengketa.

Agar perjanjian tersebut efektif dan memberikan kepastian hukum bagi para pihak yang membuatnya, kami sarankan agar tanggal pembayaran dicantumkan secara tegas.

Sesuai Pasal 1338 KUH Perdata di atas, pembuatan perjanjian harus dilakukan dengan iktikad baik.Apabila pihak perusahaan tersebut memiliki iktikad baik, seharusnya mereka 
tidak mempersoalkan mengenai pencantuman tanggal pembayaran.Justru pihak perusahaan sangat diuntungkan karena adanya kepastian pembayaran.

Namun apabila pihak perusahaan tetap berpendirian tidak mau mencantumkan tanggal pembayaran, tanpa disertai dengan alasan-alasan yang dibenarkan secara hukum, maka kami sarankan agar perjanjian tersebut diurungkan untuk mencegah timbulnya sengketa di kemudian hari.

Apabila perjanjian tersebut sudah dilaksanakan, maka dapat dikukan negosiasi kepada pihak perusahaan untuk melakukan adendum perjanjian.Adendum perjanjian ini dipergunakan saat ada tambahan atau lampiran pada perjanjian pokoknya namun merupakan satu kesatuan dengan perjanjian pokoknya.

\section{Hubungan Antara Kontrak dan Kesepakatan}

Kontrak menurut Pasal 1313 KUHPerdata adalah "perjanjian adalah suatu perbuatan dengan mana satu pihak atau lebih mengikatkan dirinya terhadap satu orang atau lebih”.Ada juga definisi kontrak yang lain yaitu, "hubungan hukum antara subjek hukum yang satu dengan subjek hukum yang lain dalam bidang harta kekayaan. Dimana subjek hukum yang satu berhak atas prestasi dan begitu juga subjek hukum yang lain berkewajiban untuk melaksanakan prestasinya sesuai dengan yang telah disepakatinya". Kontrak dan kesepakatan saling berhubungan karena kesepakatan merupakan syarat sahnya terjadinya sebuah kontrak. Sedangkan pengertian kesepakatan adalah persesuaian pernyataan kehendak antara satu orang atau lebih dengan pihak lainnya

Kesepakatan pada dasarnya, cara yang paling banyak dilakukan oleh para pihak, yaitu dengan bahasa yang sempurna secara lisan dan secara tertulis. Tujuannya pembuatan perjanjian secara tertulis adalah agar memberikan kepastian hukum bagi para pihak dan sebagai alat bukti yang sempurna, dikala timbul sengketa dikemudian hari.

\section{KESIMPULAN DAN SARAN}

\section{Kesimpulan}

a. Hukum adalah ketentuan-ketentuan yang menjadi peraturan hidup suatu masyarakat yang bersifat kendalikan, mencegah, mengikat, memaksa. Dinyatakan atau dianggap sebagai peraturan yang mengikat bagi sebagian atau seluruh anggota masyarakat tertentu, dengan tujuan untuk mengadakan suatu tata yang dikehendaki oleh penguasa tersebut. Hukum merupakan serangkaian aturan yang berisi perintah ataupun larangan 
yang sifatnya memaksa demi terciptanya suatu kondisi yang aman, tertib, damai dan tentram, serta terdapat sanksi bagi siapapun yang melanggarnya.

b. Dasar yang terdapat pada tujuan hukum adalah mewujudkan kedamaian, ketertiban, kesejahteraan, serta ketentraman dalam kehidupan masyarakat dengan sifatnya yang universal.Melalui ketentuan hukum, segala bentuk perkara akan dapat diselesaikan dengan proses peradilan yang sesuai dengan ketentuan hukum tersebut.

c. Hukum sipil (civil law) adalah sistem hukum yang berkembang di dataran Eropa. Titik tekan pada sistem hukum ini adalah, penggunaan aturan-aturan hukum yang sifatnya tertulis. Sistem hukum ini berkembang di daratan Eropa sehingga dikenal juga dengan sistem Eropa Kontinental. Kemudian disebarkan negara-negara Eropa Daratan kepada daerah-daerah jajahannya.Karakteristik utama yang menjadi dasar sistem Hukum Civil Law adalah hukum memperoleh kekuatan mengikat, karena diwujudkan dalam peraturan-peraturan yang berbentuk undang-undang dan tersusun secara sistematik di dalam kodifikasi.

d. Hukum kontrak adalah norma/ kaidah/ aturan hukum yang mengatur hubungan antara belah pihak berdasarkan kata sepakat untuk menimbulkan akibat hukum dalam melaksanakan objek perjanjian atau prestasi. Perjanjin dan kontrak bersifat bebas, selama tidak melanggar ketertiban umum, kesusilaan dan lingkungan. Dalam pasal 1233 KUHPerdt disebutkan bahwa tiap perikatan dilahirkan oleh perjanjian dan Undang- Undang.

\section{Saran}

Diharapkan ditegakannya sistem hukum yang didasarkan pada nilai filosofi yang berorientasi pada kebenaran, keadilan nilai sosial yang berorientasi pada tata nilai yang berlaku dan bermanfaat bagi masyarakat dan nilai yuridis yang bertumpu pada peraturan perundangundangan yang menjamin pada peraturan hukum/kesadaran hukum. Untuk mewujudkan sistem hukum yang dimaksud tersebut diperlukan kemampuan dan kemauan yang sungguh-sungguh untuk menegakkan prinsip-prinsip negara hukum yang sesuai dengan ketentuan hukum dan peraturan perundang-undangan yang berlaku serta pengembangan sikap perilaku patuh hukum. Kepatuhan hukum bukan sekedar kewajiban tetapi merupakan kebutuhan dalam penyelenggaraan pemerintahan maupun dalam masyarakat.

DAFTAR PUSTAKA 
Saddoen, Arifin.. "Pengertian Hukum : Karakteristik, Unsur-Unsur, Jenis-Jenis dan Tujuannya" https://moondoggiesmusic.com/pengertian-hukum/\#gsc.tab=0 (diakses pada tanggal 5 April pukul 10:12)

"Jenis-Jenis Kontrak" http://www.hukumkontrak.com/p/jenis-jenis-perikatan.html .(diakses pada tanggal 5 April 2021 pukul 10:15)

Otdidak. 2017. "Pengertian dan Jenis- Jenis Hukum Kontrak" http://itscatatanhukum.blogspot.com/2017/04/pengertian-dan-jenis-jenis-hukumkontrak.html(diakses pada tanggal 5 April pukul 10:2)

Indra. 2019. "Pembagian/ Sistematika Hukum Perdata Indonesia" https://doktorhukum.com/pembagian-sistematika-hukum-perdata-indonesia/ (diakses pada tanggal 5 April pukul 10:29)

Adytya, Billy. 2020. "15 Tujuan Hukum Menurut Para Ahli Beserta dengan Fungsinya Secara Umum" https://www.merdeka.com/trending/15-tujuan-hukum-menurut-para-ahlibeserta-dengan-fungsinya-secara-umum-kln.html?page $=2$, (diakses pada tanggal 5 April pukul 10:34)

Herawan, Wahyu Nandang. 2020. "Konsekuensi Hukum Jika Perjanjian Tak Mencantumkan Tanggal

Pembayaran"https://www.hukumonline.com/klinik/detail/ulasan/lt5e43d59cb05fe/konsek uensi hukum-jika-perjanjian-tak-mencantumkan-tanggal-pembayaran/, (diakses pada tanggal 5 April 2021 pukul 14:32)

Usman, Atang Hermawan. "Kesadaran Hukum Masyarakat dan Pemerintahan Sebagai Faktor Tegaknya Negara Hukum di Indonesia" https://core.ac.uk/download/pdf/287307509.pdf , (diakses pada tanggal 7 April 2021 pukul 20:46)

Sadi, Muhammad. 2017. Pengantar Ilmu Hukum. Jakarta : Kencana.

Hapzi Ali, Modul 1 HBL, "PENGENALAN DAN DEFINISI HUKUM SECARA UMUM" 40244-urgensi-perjanjian-dalam-hubungan-keperd-8eeedd36.pdf 